\title{
Candidate Sites for Pumped Hydroelectric Energy Storage System in Jordan
}

\author{
Salih N. Akour ${ }^{1} \&$ Anas Aref Al-Garalleh ${ }^{1}$ \\ ${ }^{1}$ Mechanical Engineering Department, School of Engineering, The University of Jordan, Amman, Jordan \\ Correspondence: Salih Akour, Mechanical Engineering Department, School of Engineering, The University of \\ Jordan, Amman 11942, Jordan. E-mail: akour@ju.edu.jo
}

Received: Nov. 22, 2018

Accepted: Dec. 4, 2018

Online Published: Jan. 14, 2019

doi:10.5539/mas.v13n2p116

URL: https://doi.org/10.5539/mas.v13n2p116

\begin{abstract}
Renewable energy sources particularly wind energy is becoming immensely popular throughout the world. Jordan is one of the countries that are interested in increasing the integration level of the wind energy on the national electrical grid. The main drawback of wind power is its inherent variability and uncertainty of source making wind energy a difficult resource to dispatch. A Pumped Hydroelectric Energy Storage (PHES) system is considered to be an attractive alternative solution for load balancing and energy storage mainly with wind farms. The current research utilizes the existing dams in Jordan as lower basin and provides candidate locations for upper pumped storage basins in the vicinity of these dams without affecting their functionality. These upper basin are semi-natural basins with least amount of construction, i.e. relatively least construction cost.

A location survey of the candidate sites in Jordan is conducted where the PHES can be implemented and operated in an efficient manner. Ten locations have been analyzed deeply in the location survey. The results show that six of them are successful candidates and appropriate locations to implement PHES system since they pass all PHES design requirements.
\end{abstract}

Keywords: pumped storage, jordan valley, natural basin, hydroelectric systems

\section{Introduction}

The renewable energy sources are steadily expanding. Many countries around the world have started to install facilities that use renewable energy sources for power generation. The importance of renewable energy sources comes together with climate change challenges associated with the excessive use of fossil fuels. There are also three main motivators that accelerate the development of renewable energy systems: energy security, economic effects, and carbon dioxide emissions restriction. The developments in technology have allowed nations to produce renewable energy more price effectively

Solar energy has a significant potential and its utilization is expanding extremely fast. It can benefit to prevent the greenhouse gasses that threaten irreversible environmental change for the world. Solar energy currently contributes a little to reduce emissions. However, it will certainly have a significant motivation in climate-friendly scenarios in the next years. Solar energy, continues to be one of the fastest-growing energy markets over the past few years. It is supposed to get a huge scale of competitiveness in the coming years.

Wind energy, is known as the most feasible as well as the most reliable among the renewable energy systems after hydropower. Recent times have experienced an acceleration in wind energy technology expansion and a rise in investment projects. Therefore, led to increase the number of experts, and achieve a significant working experience in this field all over the world.

Wind farms comprise of some individual wind turbines which are usually hooked up to the electric utility transmission network. It delivers variable power which is very steady from year to year but has a considerable variation over quite short timescales which will affect the performance of the electric power grid. Therefore, there is an urgent need to include storage systems in the power system, which aid in regulating the supplyof electricity power into the electric grid.

\subsection{Renewable Energy in Jordan}

Jordan has an excellent potential of renewable energy such as wind and solar. So it is one of the countries that is 
interested in expanding the utilization of renewable energy sector. Jordan is located within the sunbelt where the intensity of direct solar radiation is about $(5-7) \mathrm{kWh} / \mathrm{m}^{2}$. Therefore, there is a massive opportunity to use this energy (Al zou'bi, 2010).

Currently, several projects have been constructed; Two solar PV projects with total capacity of $5 \mathrm{MW}$ at Azraq in cooperation with the Spanish government are installed. Twelve PV projects achieved in 2016 to generate electricity with a total capacity of $200 \mathrm{MW}$ mostly in Ma'an and one project at Qweirah/Aqaba of a capacity of 103 MW are expected to be operated in 2017 (Jordan Ministry of Energy and Mineral Resources, 2015)

Also, Jordan is rich of wind resources. Wind speed reaches 10 to $15 \mathrm{~m} / \mathrm{s}$ in some places; mainly at high altitude locations. So it is one of the countries that are interested in wind energy since 1996. Currently time there are four wind power plants hooked up to the national grid, that are located at Ibrahimyah, Hoffa, Tafila, and Ma'an.

Ibrahimyah plant, is located $80 \mathrm{~km}$ far north of Amman, consists of 4 wind turbines with a capacity $0.08 \mathrm{MW}$ for each turbine. The Hoffa plant, is located nearly $92 \mathrm{~km}$ north of Amman, consists of 5 wind turbines with a capacity $0.225 \mathrm{MW}$ for each turbine. Tafila Wind Farm is located in Tafila Governorate in the southwest of Jordan; it is the first large-scale wind power plant. It has started producing electrical power with a capacity of $117 \mathrm{MW}$ in 2015. Ma'an Wind Park has been hooked up to the national grid with a capacity of 80 MW in 2016 (World Energy Organization, 2016) (Jordan Ministry of Energy and Mineral Resources, 2016).

These wind farms are just the beginning not the last. So a target of $10 \%$ of renewable energy input to the energy mix by 2020 is set as a goal in the national energy strategy plan. It aims mainly to increase the rated power generated from wind to $1200 \mathrm{MW}$ and from solar to $600 \mathrm{MW}$. It is obvious that wind energy sector will continue to expand in Jordan. Therefore, fail to use proper energy storage system by the electricity distribution company, will lead to lack of balance between the electricity generated by wind farms and the rate of energy demand (Rahim, 2015).

The most critical weakness of wind power is its natural variability, and also the uncertainty of source. That is why a massive range integration of wind is a danger to the stability and reliability of electric grids hosting wind energy conversion systems (Namgyel, 2012).

Pumped Hydroelectric Energy Storage (PHES) systems are considered an attractive alternative solution for load balancing and energy storage. They can supply ancillary services at high ramp rates, and they can additionally provide benefits from intraday energy price variation by releasing the energy at high demand periods, and using the energy at off-peak periods to pump water into a high potential energy reservoir (Namgyel, 2012).

\section{Literature Review}

In the last decade, interest in a large Electrical Energy Storage (EES) systems has expanded significantly as a good potential strategy to many of the issues related to renewable energy systems. One of the most significant challenges of many low-carbon generation systems is usually that they lack the same level of load-following flexibility as compared with a conventional fossil fuel power generation. This applies to renewable generation technologies which are weather conditions dependent. For instance, the wind and solar primary energy resources are varied, often unexpected.

The limited ability of the wind and solar systems to load- follow, is among the most significant problems that bulk EES aims to handle. Many research studies have considered the energy storage as an essential method of contributing the flexibility that is necessary to integrate massive proportions of renewable energy in electricity networks. Through a report that is done by (Denholm, Ela, Kirby, \& Milligan, 2010), for the National Renewable Energy Laboratory, USA, they concluded that high penetrations of variable generation extends the interest on all flexibility options, which includes energy storage systems. (Eyer \& Corey, 2010). Similar conclosion was reached by (Beaudin, Zareipour, Schellenberglabe, \& Rosehart, 2010); large-scale renewables integration would be an extra difficult challenge without energy storage. (Cochran, Bird, Heeter, \& Arent, 2012) reviewed the most suitable methods for integrating variable renewable generation to grids, and concluded that there is no one size that matches all energy demand. Therefore, that will encourage the development of energy storage systems. Although it is accepted that small percentages of renewable generation can be integrated into many electrical power systems without considerable operational variations (Gross et al., 2007).

PHES also offers various advantages throughout the power supply chain, and some research studies have presented these issues as the following (Barbour, Wilson, Radcliffe, Ding, \& Li, 2016):

- Allowing greater deployment of low-carbon generation

- Facilitating time of use energy management

- Increasing reliability for end-users 
- Minimizing the fluctuation of electricity prices

- Improving system reliability

- Maximizing system flexibility

- Reducing the need of transmission upgrades or new transmission infrastructure

- Reducing overall pollutant emissions.

PHES stores electrical energy by elevating water to upper reservoir. The charging process converts electrical energy into mechanical energy and eventually into gravitational potential energy, by using the power to pump water from a lower reservoir to a higher reservoir. The discharging process is the reverse; it converts gravitational potential energy into mechanical energy and then to electrical energy by allowing water to flow down from the higher reservoir to the lower reservoir, driving a turbine that is attached to an electrical generator. Table 1 gives some of the typical technical characteristics of PHES plants (Chen et al., 2009).

At a country level, Japan has the largest installed capacity of PHES at 25 which represents over $8.5 \%$ of its installed electricity generating capacity. China has the second largest capacity of PHES followed by the USA. However, PHES constitutes only $1.8 \%$ and $1.9 \%$ respectively of their total installed electric generation capacity GW (Deane, , Gallach, \& McKeogh, 2010).

\subsection{Advantages of PHES for Wind Integration}

The benefits associated with inserting wind power to the electrical power system is summarized as the following: 1. Reduction of total generation cost since much less fuel is used in conventional stations and 2. Reduction in carbon emission while less fossil fuel is burned. However, as a result of the natural variability of wind, expanded wind power integration can create harmful effects to the power system reliability. These types of negative impacts can potentially increase the cost of maintaining the same level of power system reliability, often called wind integration cost. Furthermore, these negative impacts can potentially offset the advantages of wind power and grow to be insignificant, as additional wind power is installed into the power system (Holttinen, 2008). It is very important to determine these types of negative impacts to make sure that they mitigate just a smaller part of the advantages. There are many scientific studies conducted on integrating PHES with wind farms as a technique to offset wind variability problems. Some advantages of PHES related to wind power integration as a result of these scientific studies are discussed by (Namgyel, 2012).

PHES is typically aligned with wind stations to increase economic profit. At certain times of low energy cost, the wind stations as an alternative to selling their power to the grid, it can be used to pump water from a lower water reservoir, and then keep in the upper reservoir. Whenever the energy price increases above a certain threshold level, stored water is released back into the lower reservoir generating electricity, and it is sold to the grid. Wind power is often sold to the grid within this period of high energy cost. In Alberta, Canada, in anticipation of future installation of $700 \mathrm{MW}$ wind energy power plant, a model which involved a 40 MW Castle River wind farm and a 40 MW PHES at Oldman dam was suggested suggested to explore these benifites. The result demonstrates that wind power generation without PHES, it is profitable, but the productivity of wind power generation increased by a factor of four when it is connected to PHES (Nickel, 2006).

PHES is commonly used in remote areas to benefit of wind power rejection. Involvement of PHES into the power system of an isolated location, helps effectively to mitigate power rejection that is generated by wind farms (Anagnostopoulos \& Papantonis, 2008).

This study explore for the opportunity of utilizing Jordan dams of being candidate sites to be part of hydropower storage system. Upon to the authors' knowledge, this is the first research that is concerned with using hydropower storage system to regulate the power supply to the national grid from the wind farms in Jordan.

\section{Problem Statement}

Jordan is one of the countries that are interested in wind power, in 2015, the first large scale wind power plantTafila wind farm has started its electrical energy production with a capacity of $117 \mathrm{MW}$. In the near future Ma'an Wind Farm will be hooked up to the national grid with a capacity of $80 \mathrm{MW}$. Through the upcoming years other farms will be installed and connected to the national grid.

The main drawback of wind power is its uncertainty of source making wind energy a difficult resource to dispatch. For this reason, large scale integration of wind is a threat to the stability of utility grids. Utility grid should consider this main issue to match the energy produced by the wind farms to the energy demand. The challenge is to find a way to make energy created by wind resources available on demand.

In Jordan, National Electric Power Company (NEPCO) control the power generation from the power plants. If the wind integration is increased it will experience difficulty on controlling power flow through the system which 
highly motivate the adoption of PHES System integration. Properly designed PHES if integrated into the Jordan power system, can offer maximum flexibility to resolve the problem of wind integration. The main objective of the current study is Site Analysis, which includes geographic data collection and proper site selection.

\section{Methodology}

Location survey is conducted to examine the candidate sites for PHES installation in Jordan. In the location survey a water balance analysis for each dam is performed and all data needed are collected from Jordan Valley Authority (JVA). All the power system data needed to accomplish this study are collected from NEPCO.

\subsection{Location Survey}

In future energy systems in Jordan with high shares of non-dispatchable renewable electricity generation, storage system will play a key role. Furthermore, the rapid increase in the expansion of renewable energy systems will lead to an urgent need to regulate the electricity flow into power networks. So, the main goal of this research is to explore the opportunity in Jordan to design a PHES system to avoid the loss of energy generated by the wind farms at off-peak demand by using the excess energy to pump water to high elevation reservoir. At peak demand, this high potential energy water will be released back to operate hydropower turbines that generate electricity according to the demand on the grid.

Jordan has many dams in the southern and northern parts of Jordan that are surrounded by mountains and hills with good heights. Six dams were built in the north and the middle of Jordan valley as it may be seen in Figure 1 with an overall storage capacity of $178.7 \mathrm{MCM}$ as it can be seen in Table 1. These dams are: King Talal, Ziglab,Wadi Al- Arab, Karameh, Shuaib and Kafrein . Three additional dams, Tannur, Mujib and Walah are in the southern part with an overall storage capacity of 57.7 MCM. AL-Wehda dam which is located on the border between Jordan and Syria has 110 MCM storage capacity. Stored water from these dams is being used for livestock, ground water recharge, irrigation and also to generate electricity by hydro generators. All needed data are obtained from JVA ("Jordan Valley Authority - Web Presence," 2017.)

\subsection{Requirements of the Candidate Sites}

In general, PHES system consists of two reservoirs with high elevation difference. The candidate locations for installation of PHES system should be situated on high elevation areas such as hill or mountain and also it should be close to water sources. The upper reservoir is on top of a mountain, whereas the lower reservoir is at the bottom of the mountain. The powerhouse with the generators is definitely in between the two reservoirs but very close to the lower reservoir. One of the aims of this research is to search for suitable natural basins nearby an existing water reservoirs (dams). To decrease the construction cost of PHES system, the location should have the following properties:

1. The nature of the site should be able to keep water.

2. The elevation between the upper and lower reservoirs should be high enough to allow construction of PHES. For a certain power station, the reservoir storage requirement and the capacity of the water conduit are inversely proportional to head. Therefore, the cost of the reservoir and water conduit is greatly reduced when the site has a high head.

3. The distance of water conduit has to be as short as possible. This is mainly necessary for the locations with the lower head. The economic length for a water conduit is function of head and can be identified in terms of the whole length to head $(\mathrm{L} / \mathrm{H})$ ratio. The maximum acceptable $\mathrm{L} / \mathrm{H}$ ratio range is from 10 to 12 for high-head sites (360 $\mathrm{m}$ and above) and about 4 to 5 for low-head sites (150-180 m) (Namgyel, 2012).

4. Upper candidate reservoir should be natural or semi-natural basin that needs least construction work to reduce the capital cost.

5. The candidate sites should be located close to the national electric grid to reduce power transmissions cost. 


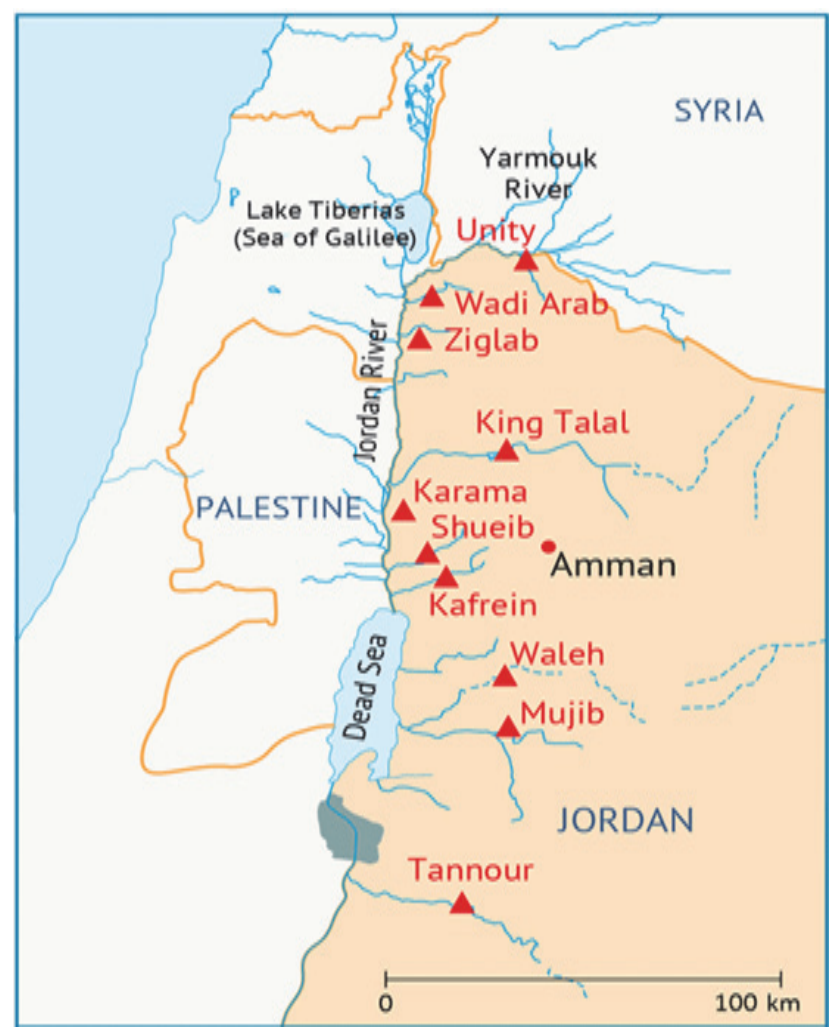

Figure 1. Dams in Jordan (Fanack Water, 2016)

\subsection{Energy Storage Capacity}

To determine the amount of energy that can be stored by the PHES system in a dam. The volume of water that is needed to estimate the electrical energy that can be converted into potential energy in the high elevation storage can be calculated according to the following steps:

1- Identify the rated pumping head.

2- Calculate the volume flow rate of water when pump operates with $1 \mathrm{MW}$ rated power to elevate water to rated head into upper reservoir by using equation (1)

$$
Q_{P}=\frac{P_{P} \times \eta_{P}}{g \times \rho \times h}
$$

Where: $Q_{P}$ : Rated volume flow rate $\left(\mathrm{m}^{3} / \mathrm{s}\right) . P_{P}$ : Rated Pump Power $(W) . \eta_{P}$ : Pump efficiency. $g$ : Acceleration of gravity $\left(9.8 \mathrm{~m} / \mathrm{s}^{2}\right) . \rho$ : Density of water $\left(1000 \mathrm{Kg} / \mathrm{m}^{3}\right) . h$ : Head $(m)$.

3- Identify pump continuous operation time in hours at a rated power in a certain interval.

4- The required volume of the upper reservoir for $1 \mathrm{MW}$ rated pumping power can be estimated by using equation 2.

$$
V_{R}=Q_{P} \times T
$$

Where: $V_{R}$ : Volume of the upper reservoir. $T$ : Rated pumping time in second.

Divide the minimum volume storage capacity required for upper basin by the volume estimated for $1 \mathrm{MW}$ rated pumping power will provide the rated power storage capacity.

\section{Analysis of Candidate Sites in Jordan}

It is important to mention that the geographical requirements of the candidate sites are not easy to be met. However, it is necessary to explore and find the best locations that can achieve the maximum possible of PHES implementation requirments to reduce the capital infrastructure cost of the whole project. Jordan has a good potential sites to utilize this kind of storage system as result of the natural terrain's specifications nearby the dams. All the dams are connected to the national electric grid. The energy storage analysis for upper basin volume is carried based on the least water storage available during the years 2011 through 2017. 


\subsection{King Talal Dam}

As shown in Figure 2, King Talal Dam is huge dam located in the northern mountains of Jordan, across the Zarqa valley. As shown in table 1 the dam was initiated in 1971, with the primary construction getting completed in 1978 at an elevation of 92.5 meters. In 1984, to match the country's increasing water demands, the dam was expanded to a height of 106 meters in 1988. The main purpose of the dam is to store rain water, to utilize sewage water that is drawn from Amman and Zarqa to be treated in As-Samra station, to irrigate Jordan Valley farms and to generate electricity. There are two small hydro power units (Francis turbine) installed in King Talal Dam with rated capacity of $5 \mathrm{MW}$.

King Talal Dam has an excellent potential to construct PHES system as shown in Figure 2. Two candidate locations $\mathrm{A}$ and $\mathrm{B}$ are identified and they have proper height difference that ranges from 200 to $220 \mathrm{~m}$ respectively. Both sites are natural basins. This is advantageous regarding the construction cost, (i.e. reducing the electrical power transmission lines expenses). Figure 2 presents that the distance between the upper and bottom storage for location A is approximately $1.33 \mathrm{~km}$ which is acceptable from design point of view. The elevation of upper storage is 384 $\mathrm{m}$ above the sea level, whereas the powerhouse location hieght is $179 \mathrm{~m}$ above the sea level near the end of the hill.

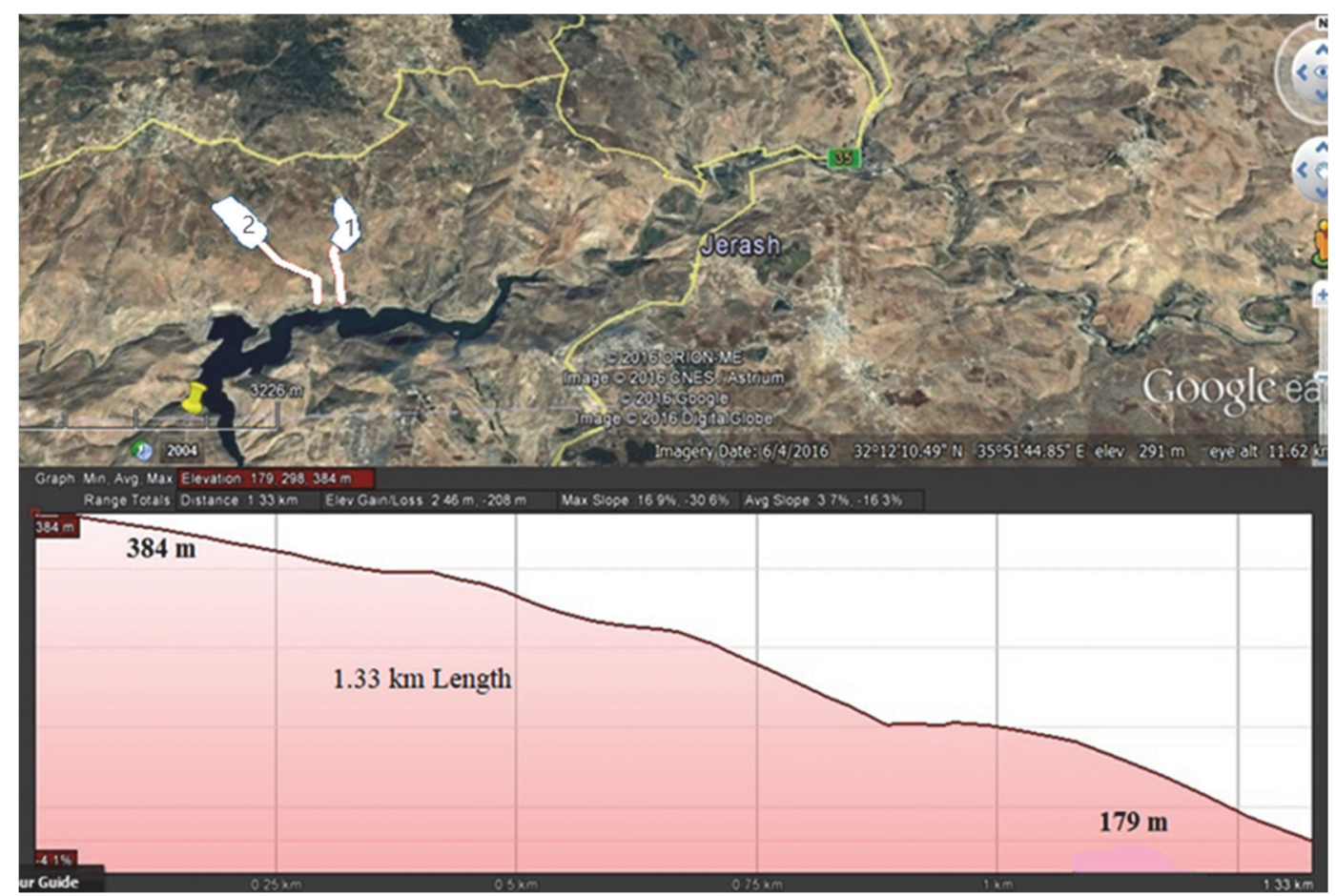

Figure 2. Elevation profile of candidate location in King Talal dam

To estimate the amount of electrical energy that can be stored in the proposed PHES system at King Talal dam, an intensive analysis of the water balance for the dam including the storage volume, inflow and outflow rate volume for at least 3 years should be performed to guarantee that the water level is available all through a year that will make the PHES work properly. The capacity storage of King Talal dam is $74 \mathrm{MCM}$. Figure 3 shows the water balance through the period from 2011 to 2017 . The minimum value of storage volume through this period was about 20 MCM that was reached on January first of years 2011/2012/2013. 


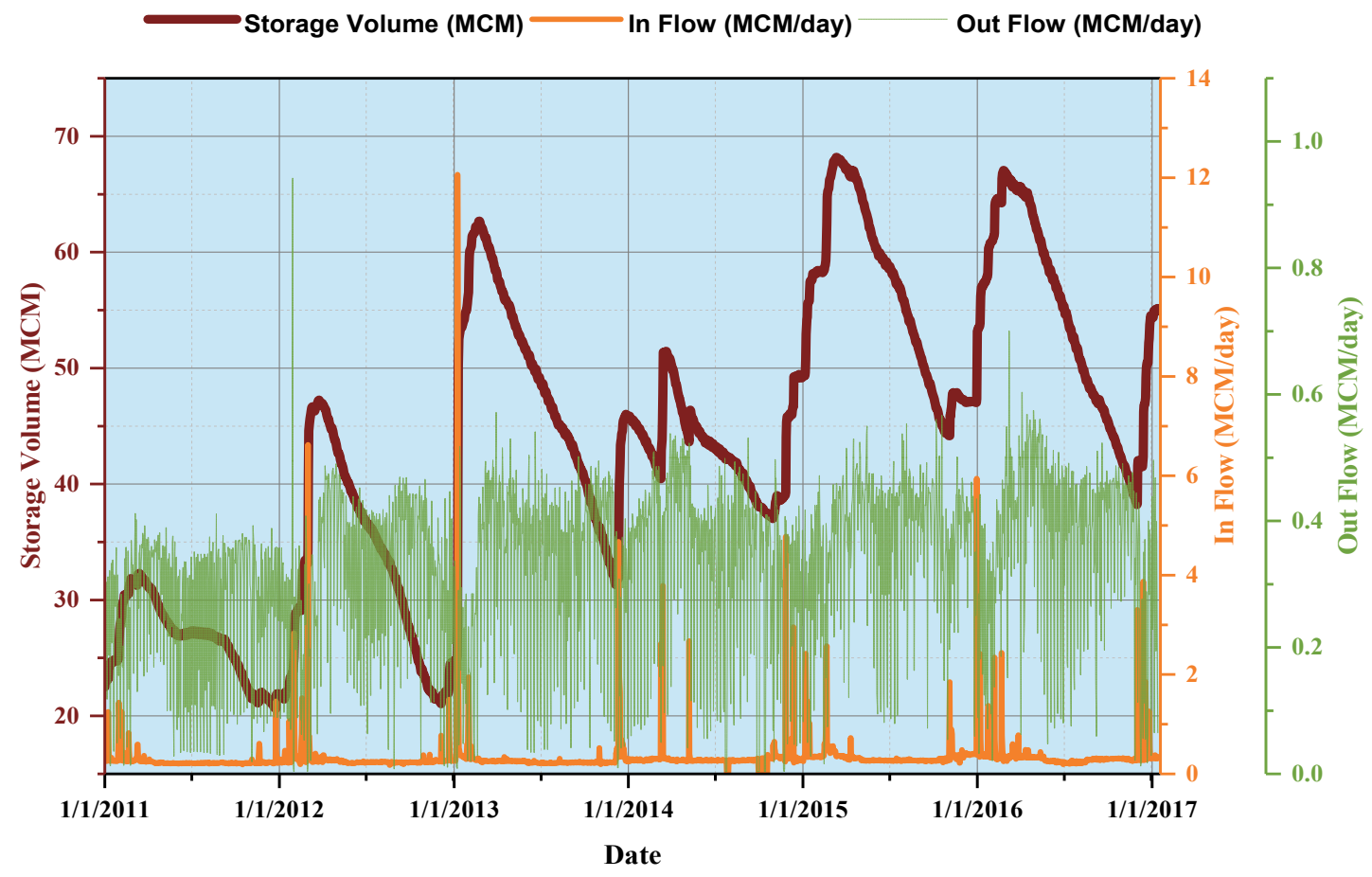

Figure 3. Water balance of King Talal dam

By applying the procedure in section 4.3, the volume of water that is needed to operate PHES system in the candidate locations in king Talal dam can be calculated. For the rated pumping head of the proposed site that has height difference $205 \mathrm{~m}$ and for $1 \mathrm{MW}$ rated power comtinously operated for 12 hours, the required volume of upper baisn is found to be $19.3 \times 10^{3} \mathrm{~m}^{3}$.

The energy storage capacity of $20 \mathrm{MCM}$ upper basin for 12 hours pumping time is $1036.26 \mathrm{MW}$, i.e., the total energy storage capacity is $12.4 \mathrm{GWhr}$. This is $100 \%$ of minimum stored water volume that King Talal dam reached on first January of years $2011 / 2012 / 2013$. As presented in Table 1 the projected area of the first location is $190.6 \times 10^{3} \mathrm{~m}^{2}$ and for the second location is $310.4 \times 10^{3} \mathrm{~m}^{2}$. So an average depth needed from both sites to store such amount of energy is $40 \mathrm{~m}$.

\subsection{Al-Wehdah Dam}

As shown in Figure 4, AL-Wehdah dam is an 110-m height roller-compacted concrete gravity dam on the Yarmouk River at the border between Syria and Jordan. It is able to hold up to $115 \mathrm{MCM}$ of water which is constructed to supply Jordan with water for both human consumption and agriculture. Table 1 shows the specifications of this dam.

Al-Wehdah dam is also considered to be a Suitable site to install PHES systems as shown in Figure 4. Three locations are identified which have proper height difference that ranges from 265 to $275 \mathrm{~m}$ and have enough suitable area for each place where the upper reservoir can be constructed.

Figure 4 illustrates the distance between the upper and lower storage is varying from $570 \mathrm{~m}$ to $612 \mathrm{~m}$ which fulfills the design requirements. The elevation of upper storage is $349 \mathrm{~m}$ above the sea level, whereas the powerhouse location height is $84 \mathrm{~m}$ near the end of the hill.

The capacity storage of Al-Wehdah dam is 115 MCM. Figure 5 shows the water balance, inflow and outflow through years from 2011 to 2017. The minimum storage volume through this period was about $5 \mathrm{MCM}$. Following the prodecure in section 4.3 for $1 \mathrm{MW}$ pumping power at rated pumping head of the proposed site of $265 \mathrm{~m}$ and continuously pumping time of 12 hours, the required volume of upper basin is $14.9 \times 10^{3} \mathrm{~m}^{3}$. For upper basin having water storage capacity of 5MCM (minimum stored volume that Al-Wehdah dam has reached in 28/10/2011, and $23 / 8 / 2012$ ) the power rated capacity is $335.57 \mathrm{MW}$, i.e, total energy storage capacity for 12 hours continuous pumping time is $4.0 \mathrm{GWhr}$. 


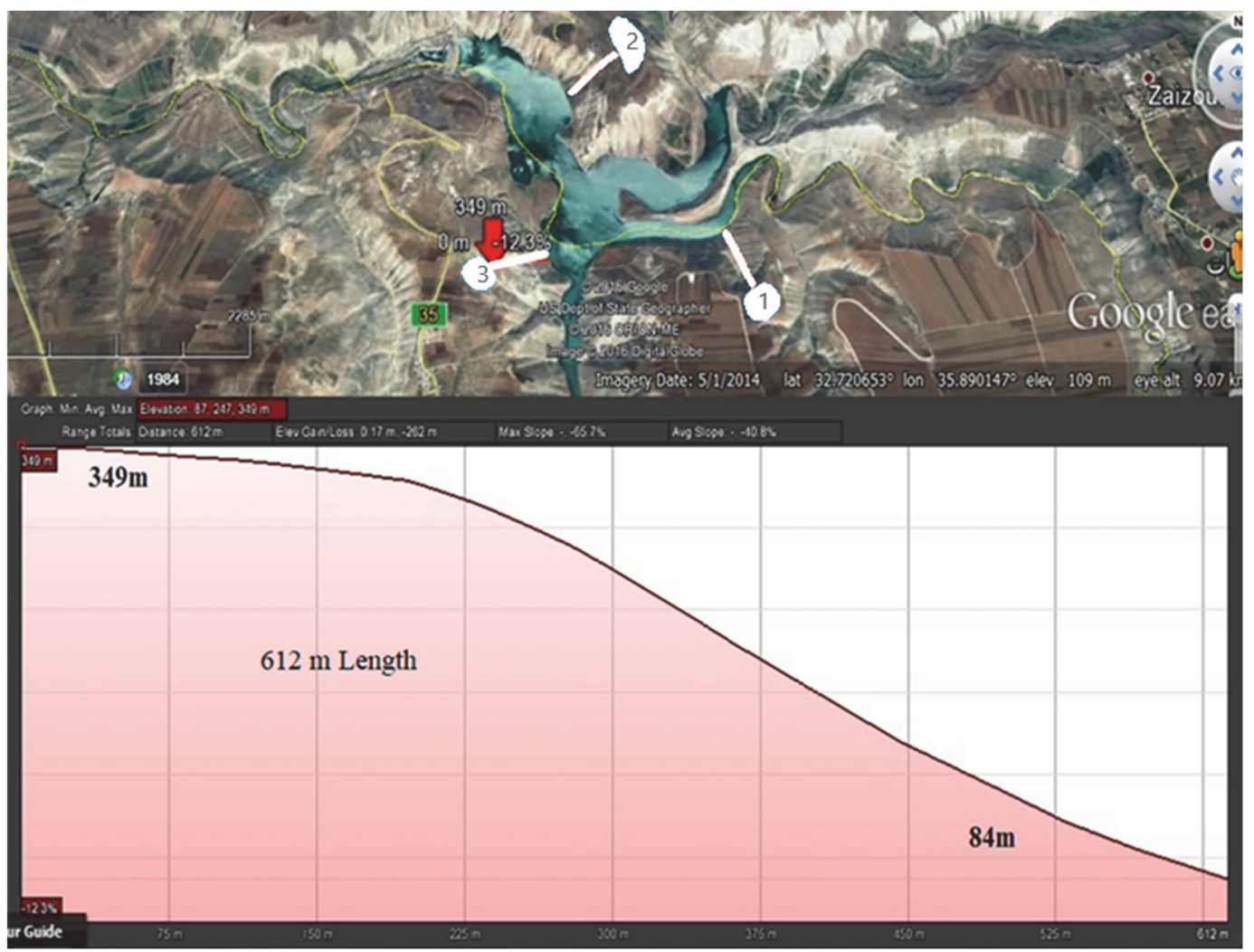

Figure 4. the curve in the bottom graph shows the Elevation difference profile between the points $\mathrm{A}$ and B marked in the picture of Al-Wehdah dam.

As shown in Table 1 the projected area of the first location is $70 \times 10^{3} \mathrm{~m}^{2}$, the second location is of $126.2 \times 10^{3} \mathrm{~m}^{2}$ and the third location is $60 \times 10^{3} \mathrm{~m}^{2}$. For example the average depth needed for the second location to achieve $335.57 \mathrm{MW}$ is $39.6 \mathrm{~m}$ depth.

Storage Volume (MCM) $\longrightarrow$ In Flow (MCM/day) O Out Flow (MCM/day)

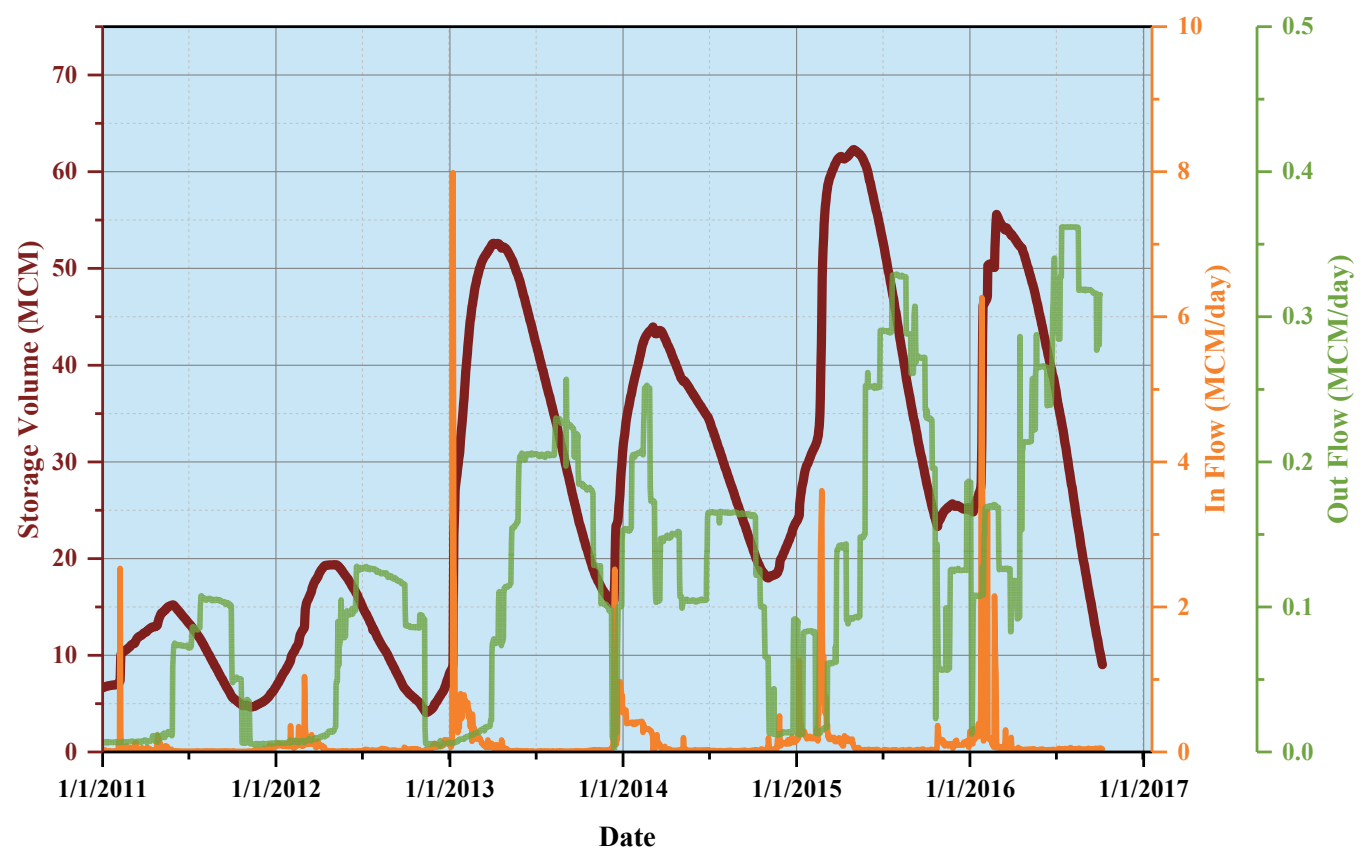

Figure 5. Water balance for Al-Wehdah dam 


\subsection{Wadi Al-Arab dam}

As shown in Figure 6 Wadi Al-Arab dam is located in the northern part of Jordan valley, about $10 \mathrm{~km}$ south of the Tiberias lake and $25 \mathrm{~km}$ from Irbid City. The water arrives partially from the King Abdallah Canal that draws water from Jordan river and partly from precipitation. The water is utilized to irrigate about $12.5 \times 10^{6} \mathrm{~m}^{2}$ of land starting from Al Shuna to Al Baqura. Table 1 shows the dam characteristics.

Wadi Al-Arab dam is situated in terrain which has excellent potential to construct PHES system. One candidate location as shown in Figure 6, with a proper elevation which is about $270 \mathrm{~m}$, and has enough suitable area where the upper reservoir can be constructed.

Figure 6 shows the distance between the upper and lower storage is found to be $900 \mathrm{~m}$. The elevation of upper storage is $170 \mathrm{~m}$ above the sea level, whereas the powerhouse location height is $(-100 \mathrm{~m}$, below sea level) which meets the design requirments.

As in Table 1 the water storage capacity of Wadi Al-Arab dam is $16.8 \mathrm{MCM}$. The minimum storage volume through the period of 2011 to 2017 is about 1.6 MCM that took place in November 9, 2012.

For the rated pumping head at proposed site of $270 \mathrm{~m}$, assuming $1 \mathrm{MW}$ pumping power for 12 hour continuous operation for 12 hours, the required storage volume is $14.7 \times 10^{3} \mathrm{~m}^{3}$.

14

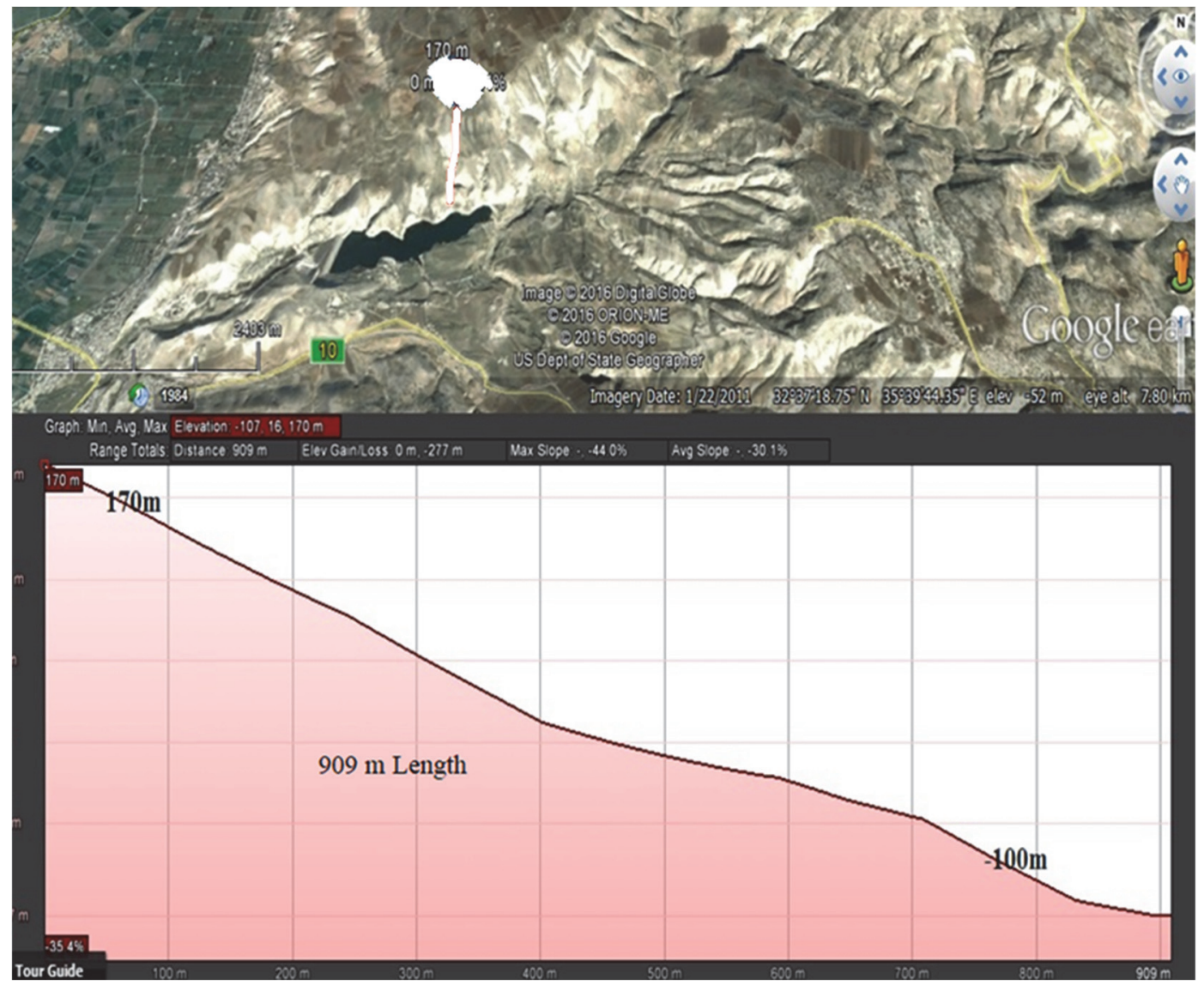

Figure 6. Elevation profile of candidate location in Wadi Al-Arab dam

For 1.6 MCM water storage capacity for the upper basin, the rated storage power is $114.3 \mathrm{MW}$, i.e., the total energy storage capacity for 12 hours continuous pumping time is $1.37 \mathrm{GWhr}$. As shown in Table 1 the projected area of the proposed location is $247 \times 10^{3} \mathrm{~m}^{2}$, so the average depth needed to store $114.3 \mathrm{MW}$ is $6.5 \mathrm{~m}$ depth.

In summary as shown in Table 1 the candidate location has large area with proper elevation which means that it is a favorable site but the concern here is the small dead volume limit of the dam which is $1.6 \mathrm{MCM}$. So it is recommended in the future to increase the dam dead limit, to allow PHES system work in an efficient manner. 


\subsection{Al-Mujib Dam}

As shown in Figure 7 Al-Mujib dam is situated in Wadi Mujib, between the governates of Madaba and Al-Karak. It is a rolled concrete (RCC) dam with abutments of clay-core rockfill. The construction work has finished in 2004, after six years of construction. Table

Al-Mujeb dam is considered to be a Suitable site to install PHES system as shown in Figure 7. One location is identified which has proper height difference of $511 \mathrm{~m}$. The location has enough suitable area where the upper reservoir can be constructed. But the earth layers there are mainly basalt which may need additional cost to install the storage.

As shown in Figure 7 the distance between the upper and lower storages is approximately $2.55 \mathrm{~km}$ which is acceptable from design point of view. The elevation of upper storage is found to be $707 \mathrm{~m}$ above the sea level, whereas the anticipated powerhouse location height is $196 \mathrm{~m}$ near the end of the mountain.

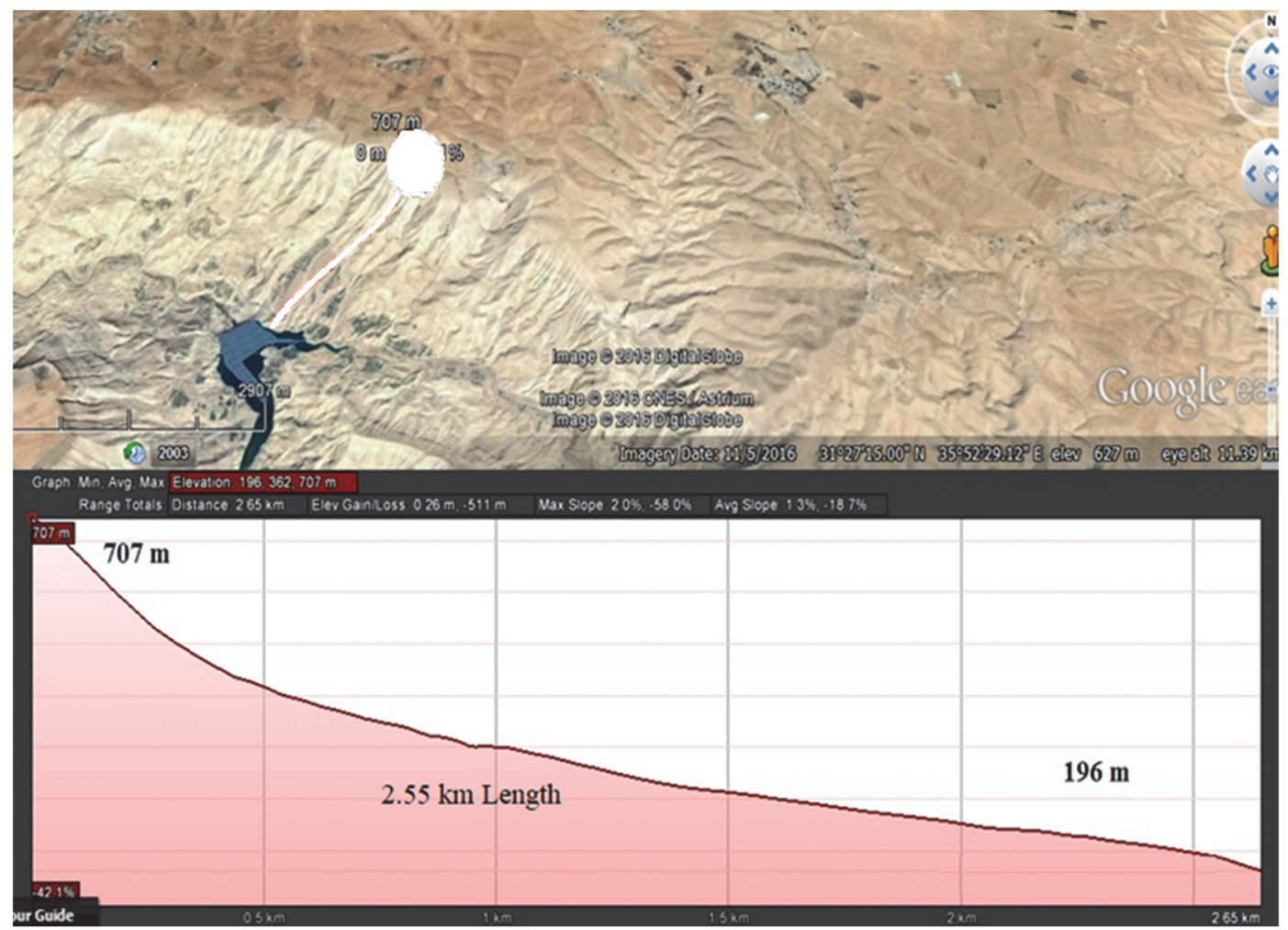

Figure 7. Elevation profile of candidate location in Al-Mujib dam

As in Table 1 the capacity storage of Al-Mujeb dam is $31.2 \mathrm{MCM}$. The minimum value of storage volume through the period from 2011 to 2017 is about 5 MCM that took place in 8/1/2013.

For the rated pumping head at proposed site of $511 \mathrm{~m}$ and $1 \mathrm{MW}$ pumping power assuming continuous pumping for 12 hours, the required storage volume is $7.7 \times 10^{3} \mathrm{~m}^{3}$. For $5 \mathrm{MCM}$ water capacity for the upper reservoir, the rated power for continuous pumping of $12 \mathrm{hr}$ is $649.35 \mathrm{MW}$, i.e., the total energy storage capacity for 12 hours continuous pumping time is $7.79 \mathrm{GWhr}$. As shown in Table 1 the area of the first location is $285.6 \times 10^{3} \mathrm{~m}^{2}$ so the needed average depth is $17.5 \mathrm{~m}$.

In summary, Al-Mujeb dam is the best site to construct this storage system in Jordan, it has a high elevation up to $511 \mathrm{~m}$ and acceptable distance between the upper and lower storages.

\subsection{Al-Walah Dam}

As shown in Figure 8, Al-Walah dam is located at about $60 \mathrm{~km}$ south of Amman city at wadi Al-Wala. The dam construction was started in 1999 and finished in 2002. Also, the impoundment was initiated in 30/10/2002. As shown in Table 1 it is RCC Central section with over flow stepped spillway and zoned earth fill wing embankments. The objectives of the dam are for Industrial supply, irrigation and recharge.

Al-Walah dam is situated in a terrain which has excellent potential to construct PHES system. One candidate 
location is identified as shown in Figure 8, which has a proper height difference is found to be $131 \mathrm{~m}$, and has enough suitable area where the upper reservoir can be constructed.

Figure 8 indicates that the distance between the upper and lower storage is approximately $550 \mathrm{~m}$ which fulfill the design requirments. The elevation of the proposed upper storage is found to be $646 \mathrm{~m}$ above the sea level, whereas the anticipated powerhouse location height is $515 \mathrm{~m}$ near the end of the hill.

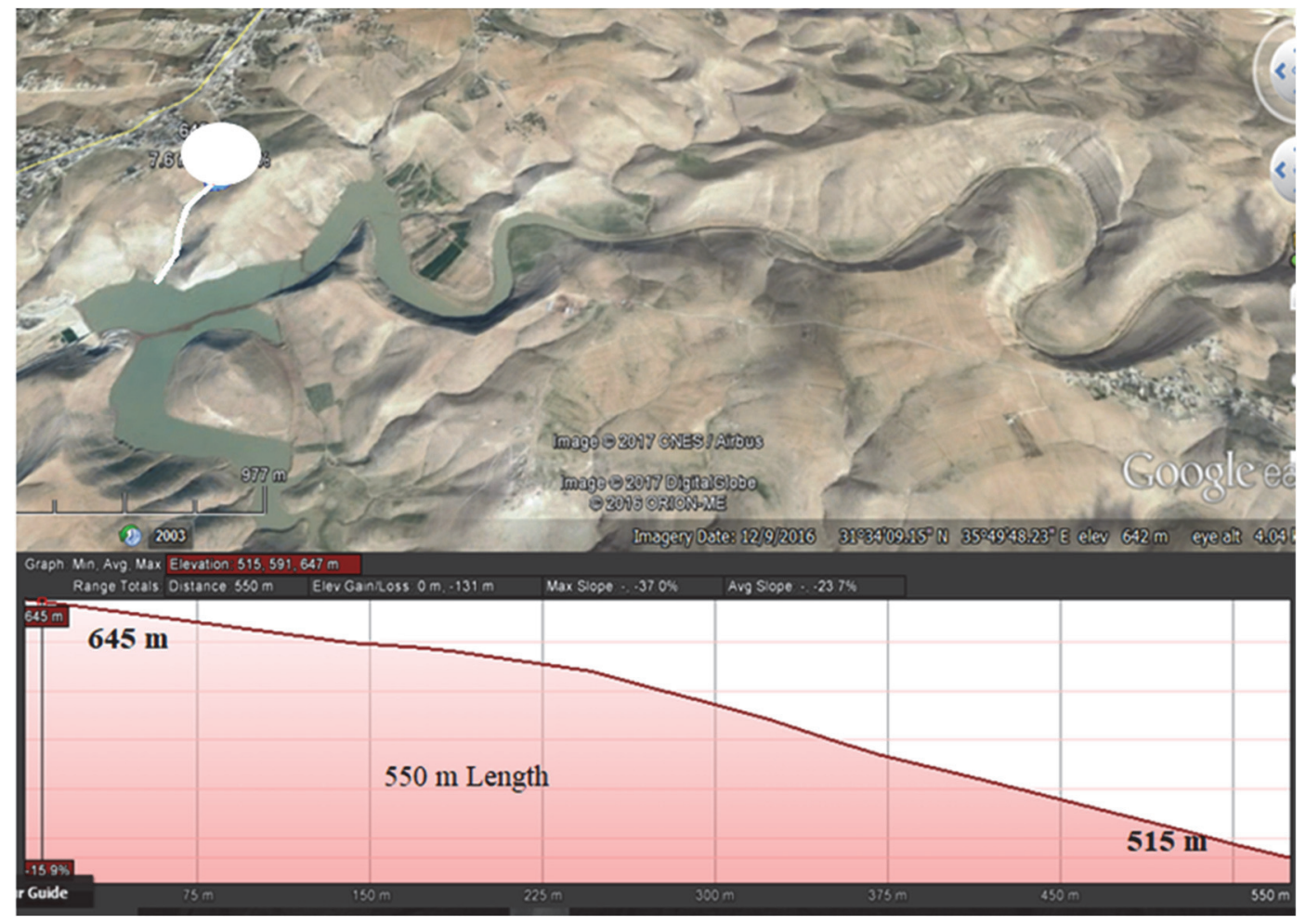

Figure 8. Elevation profile of candidate location in Al-Walah dam

As in Table 1 the capacity storage of Al-Walah dam is 9.3 MCM. The water balance. The minimum value of storage volume through the period from 2011 to 2017 was found to be 1.2 MCM that took place 9/1/2012.

For rated pumping head at the proposed site of $131 \mathrm{~m}$ and $1 \mathrm{MW}$ pumping power that is continuously operated for 12 hours, the required volume of upper storage is found to be $30.2 \times 10^{3} \mathrm{~m}^{3}$. For $1.2 \mathrm{MCM}$ the rated power for continuous pumping of $12 \mathrm{hr}$ is $39.7 \mathrm{MW}$, i.e., the total energy storage capacity for 12 hours continuous pumping time is $476.4 \mathrm{MWhr}$. As shown in Table 3.10 the area of the proposed upper basin location is $40 \times 10^{3} \mathrm{~m}^{2}$, the required average depth is $30 \mathrm{~m}$.

\subsection{Al-Tannur Dam}

Al-Tannur dam as shown in Figure 9 is located in Tafila government south of Jordan, at Wadi AL Hissa. The construction was started in 1999 and completed in 2001. As indicated in Table 1 it is RCC with overflow stepped spillway. The main Purpose of the dam is Irrigation.

Al-Tannur dam has a good potential to construct PHES system. As shown in Figure 9 two candidate locations are identified which have proper height difference that ranges from 340 to $350 \mathrm{~m}$ and have enough suitable area where the upper reservoir can be constructed.

The second location situated in Basalt Mountain and it is a natural basin. Figure 9 indicates that the distance between the upper and lower storages for the first location is approximately $1.5 \mathrm{~km}$. which is acceptable from design point of view. The elevation of the proposed upper storage is found to be $739 \mathrm{~m}$ above the sea level, whereas the powerhouse anticipated location height is $390 \mathrm{~m}$ near the end of the hill.

As in Table 1 the capacity storage of Al-Tannur dam is $16.8 \mathrm{MCM}$. The water balance. The minimum value of storage volume through the period from 2011 to 2017 was about 1.9 MCM that occurred in 2/1/2013.

For rated pumping head at the proposed site of $349 \mathrm{~m}$, and $1 \mathrm{MW}$ pumping power continuously operated for 12 
hours, the required volume of the upper storage is $11.3 \times 10^{3} \mathrm{~m}^{3}$. The rated power for $1.9 \mathrm{MCM}$ upper basin storage of $12 \mathrm{hr}$ continuous pumping is $168.14 \mathrm{MW}$, i.e., the total energy storage capacity for 12 hours continuous pumping time is $2.0 \mathrm{GWhr}$. As shown in Table 1 the area of the first location is found to be $96 \times 10^{3} \mathrm{~m}^{2}$, so the required average depth to store $1.9 \mathrm{MCM}$ of water is $19.8 \mathrm{~m}$.

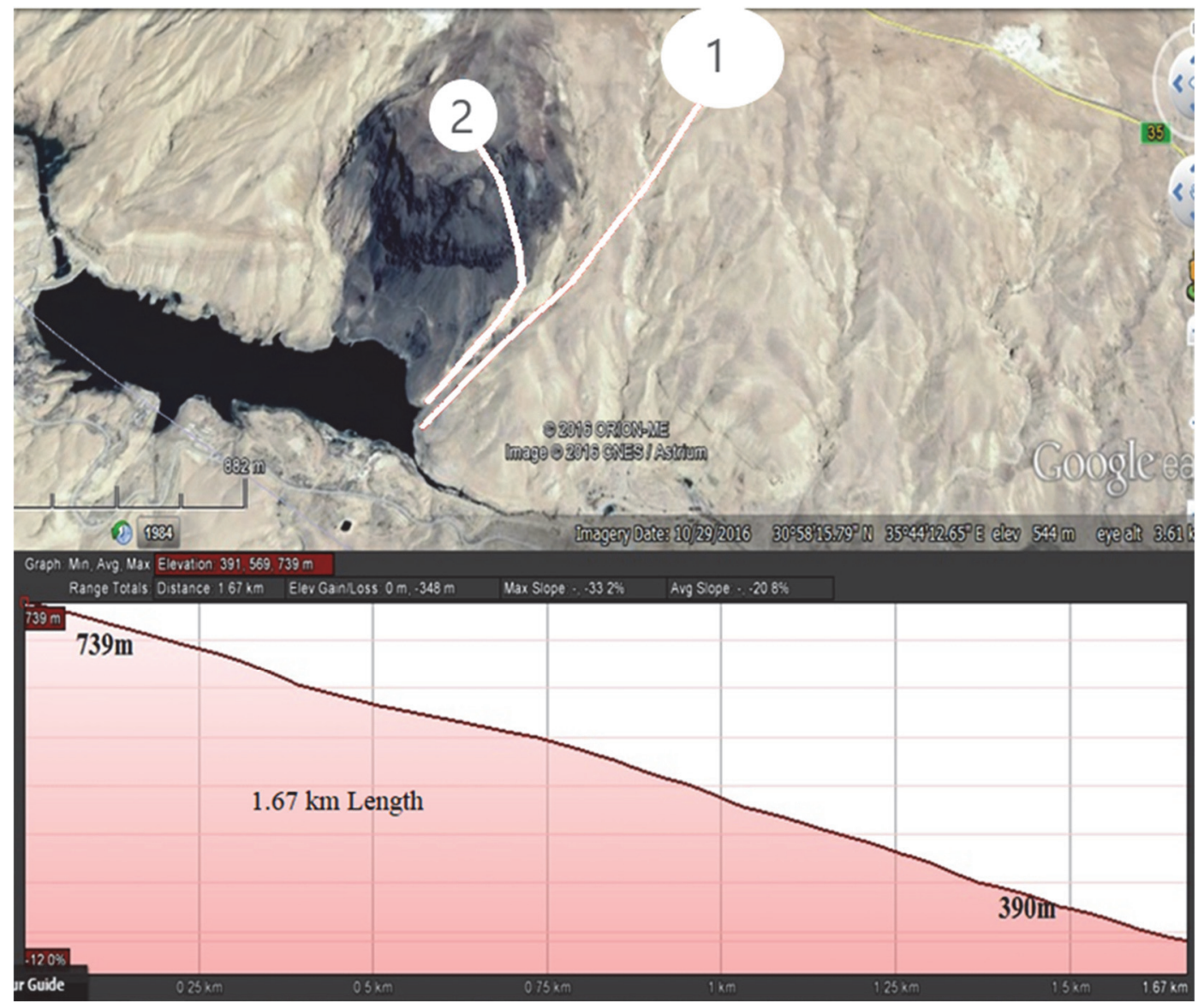

Figure 9. Elevation profile of candidate locations in Al-Tannur dam

\subsection{Poor Opportunity Sites}

Some dams in Jordan do not have the minimum requirements of the considered design criteria to establish energy storage system which are the height difference, available volume of water, and suitable area to construct upper storage. These sites include: Ziglab, Karamah, Shuaib and Kafrein dams. Table 2 shows the specification for each dam.

As shown in Figure 10 The water balance for Ziglab, Shuaib and Kafrein dams indicates that they don't have suitable volume storage and also, they frequently reach the least amount level of storage capacity.

As shown in Table 2 Al-Karamah dam has large storage capacity. Figure 11 shows the water balance analysis for Al-Karamah dam which indicates that it has good potential volume storage but the nearby terrain does not have suitable height difference; the terrain around the dam almost has similar elevation. 


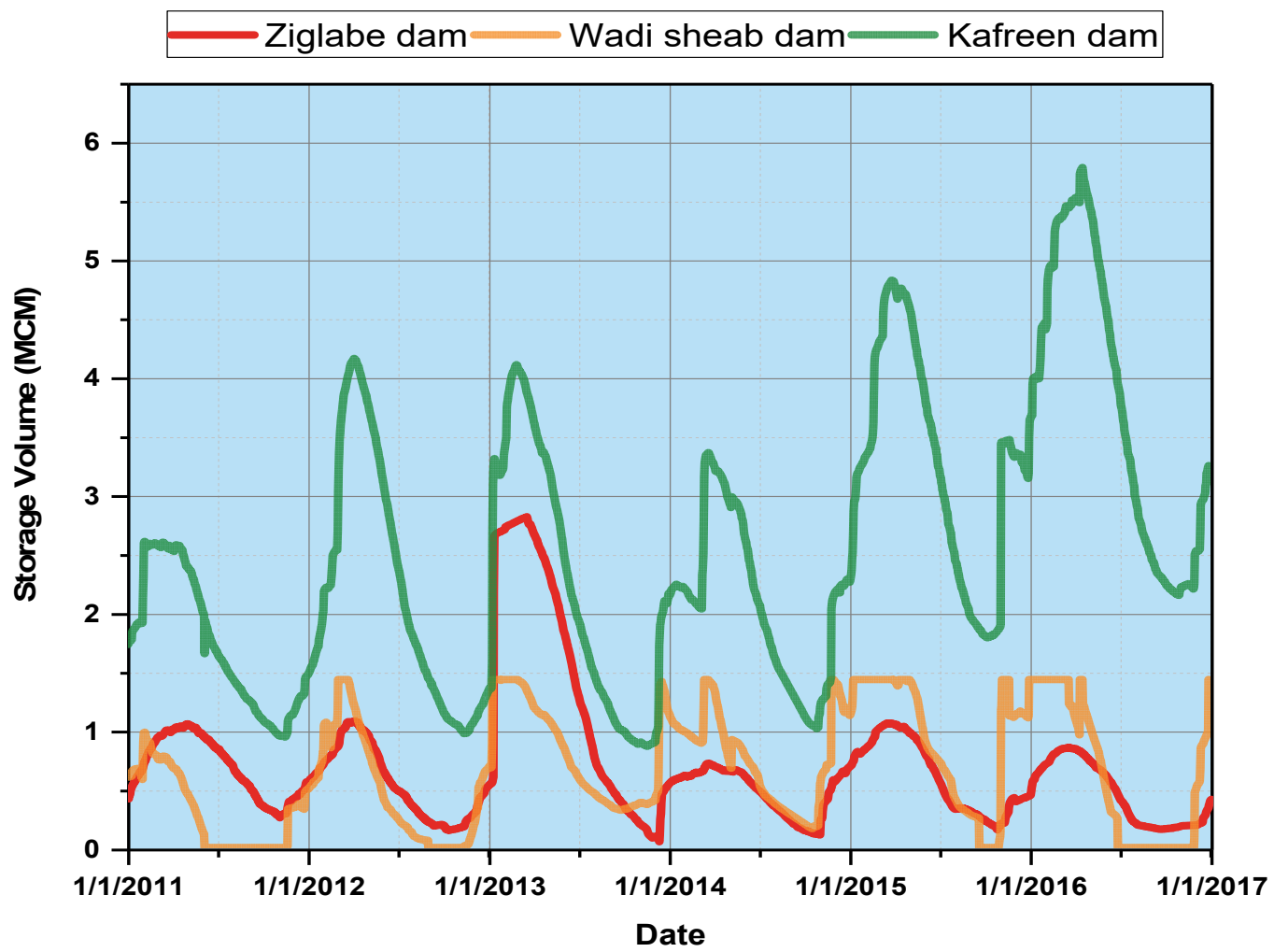

Figure 10. Water balance for Ziglab, Wadi Shuib and Kafrein dams

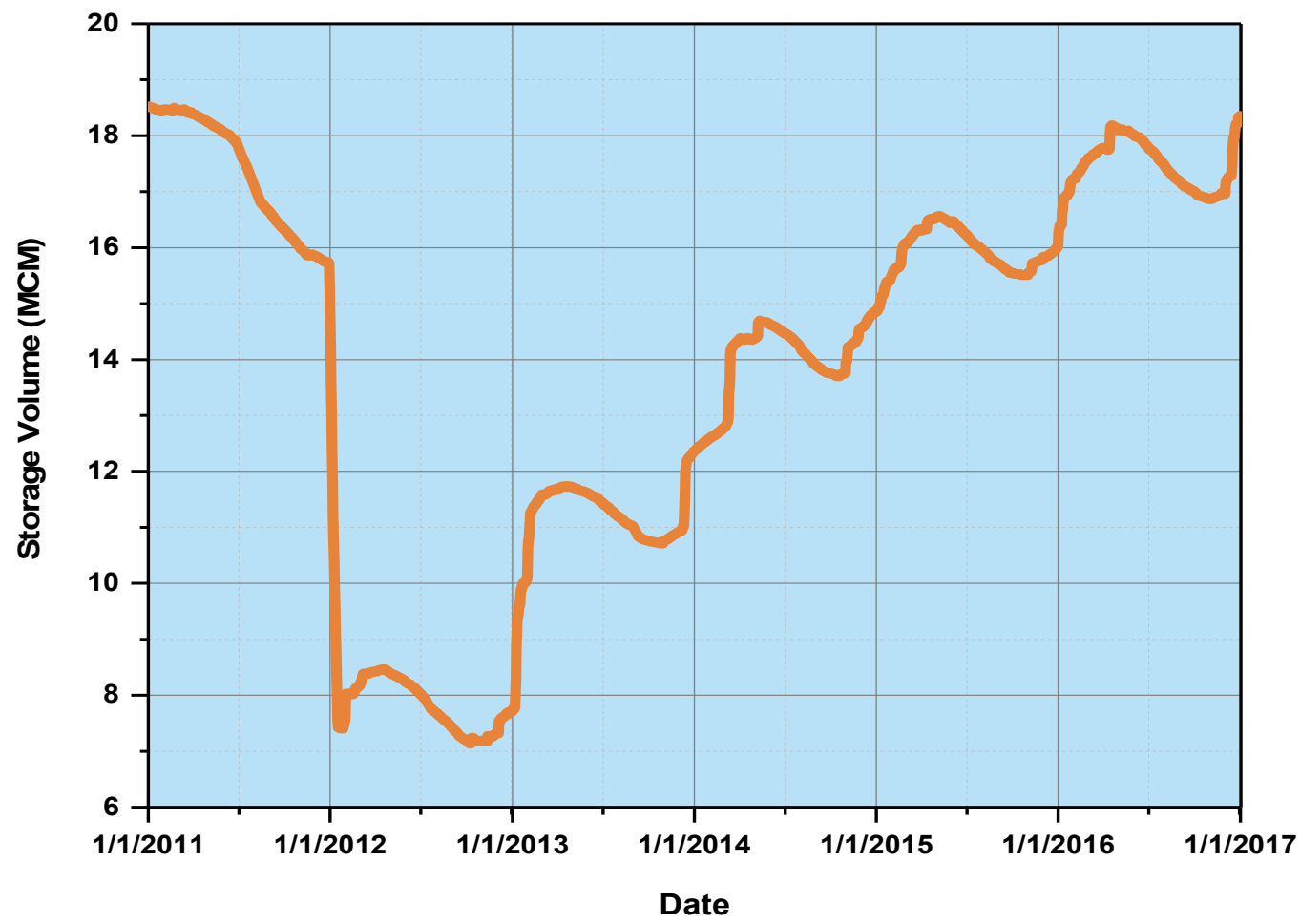

Figure 11. Water balance Conclusions \& Recommendations

\section{Conclusions}

This research has studied the impact of PHES inclusion in the power system along with the increase of wind power 
integration level in Jordan. Location survey has been conducted to examine the candidate sites for PHES installation in Jordan. This study has concluded the following issues:

- Jordan has a very promising potential to install PHES due to the achievement of the basic conditions for implementing such system.

- Ten dams have been analyzed by studying the geographical nature of the terrain nearby the dam. Also, a water balance for each dam has been studied to ensure that the water volume is always available when the dam drawn to minimum level.

- King Talal, Al-Wehdah, Wadi Al-Arab, Al-Tannur, Al-Mujib and Al-Walah dam, they all have achieved the basic requirements to install PHES.

- Al-Karamah, Ziglab, Shuib, and Al-Kafrien dam, none of them has met the basic requirements to install PHES due to the minimum available water value and the height difference are relatively small.

- The existence of the upper natural or semi-natural basin will increase the storage capacity of the dams when these basins are made larger than what is needed for PHES. This will improve water national security.

- It is obvious that the minimum storage level in the dams occurs in years 2011 through 2013 . This is due to the over use of water resources because of the refugees of the neighboring countries.

Jordan Suffers lack of energy resources besides the continuous growth in the demand load. Therefore, the clean and local energy resources such as wind energy are very important to meet the consumers' demand with lower cost and lower emissions. However, higher integration level of renewable energy sector particularly wind power may affect the stability of the national power grid. PHES offers the ability to solve this issue.

PHES system can enhance the energy sector by matching the power generation of the renewable energy resources with the demand load. That will lead to increase the integration level of renewable energy and reduce the total generating cost in the whole power system.

This research provided a clear study on the possibility of utilizing PHES in Jordan. Therefore, it is recommended to include PHES system in the national plan for the exploitation and development of the energy sector.

Table 1. Data of the dams that successfully fulfilled the storage design criterion.

\begin{tabular}{|c|c|c|c|c|c|c|c|c|c|c|}
\hline Dam Name & & & & $\begin{array}{l}\frac{\pi}{\pi} \\
\frac{\pi}{0} \\
\sum_{1} \\
\frac{1}{4}\end{array}$ & & & & 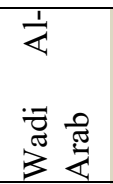 & $\frac{0}{\sum_{i}^{2}}$ & $\begin{array}{l}\frac{\pi}{\pi} \\
\frac{\pi}{2} \\
\frac{1}{2}\end{array}$ \\
\hline Location No. & 1 & 2 & 1 & 2 & 3 & 1 & 2 & 1 & 1 & 1 \\
\hline $\begin{array}{l}\text { Candidate } \\
\text { Coordinates }\end{array}$ & 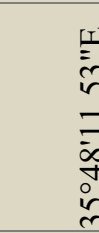 & 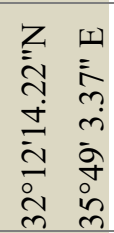 & 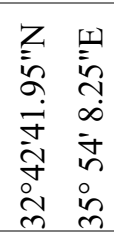 & 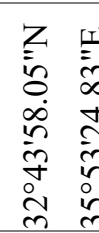 & 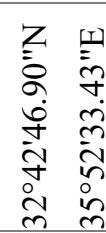 & 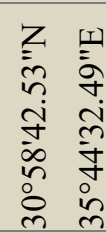 & 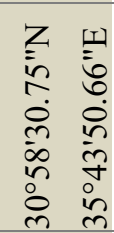 & 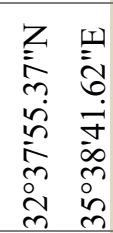 & 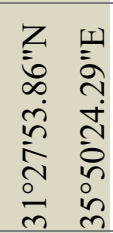 & 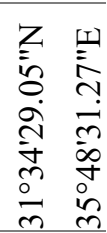 \\
\hline $\begin{array}{l}\text { Projected area } \\
\left(1000 \mathrm{~m}^{2}\right)\end{array}$ & $\begin{array}{l}\dot{0} \\
\dot{9}\end{array}$ & $\stackrel{+}{\circ}$ & $\stackrel{\circ}{\circ}$ & 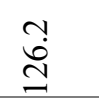 & $\stackrel{8}{8}$ & $\ddot{\circ}$ & $\stackrel{\circ}{m}$ & 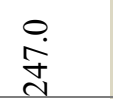 & $\begin{array}{l}0 \\
\dot{\delta} \\
\infty \\
i\end{array}$ & $\stackrel{\dot{q}}{\dot{q}}$ \\
\hline $\begin{array}{l}\text { Dam Elevation wrt } \\
\text { Sea Level }\end{array}$ & 179 & 179 & 84 & 84 & 84 & 390 & 390 & -100 & 196 & 515 \\
\hline $\begin{array}{l}\text { Upper Basin } \\
\text { Elevation wrt Sea } \\
\text { Level }\end{array}$ & 384 & 384 & 350 & 350 & 350 & 739 & 710 & 170 & 707 & 646 \\
\hline $\begin{array}{l}\text { Height Difference } \\
\text { (m) }\end{array}$ & 205 & 205 & 266 & 266 & 266 & 349 & 320 & 270 & 511 & 131 \\
\hline $\begin{array}{l}\text { Dam Capacity } \\
\text { (MCM) }\end{array}$ & 74 & & 115 & & & 16.8 & & 16.8 & 31.2 & 9.3 \\
\hline $\begin{array}{l}\text { Minimum water } \\
\text { level in the past } 7 \\
\text { year in MCM }\end{array}$ & 20 & & 5 & & & 1.9 & & 1.6 & 5 & 1.2 \\
\hline $\begin{array}{l}\text { Approximate } \\
\text { Energy Storage } \\
\text { Capacity (MWhr) }\end{array}$ & 12500 & & 4000 & & & 2000 & & 1370 & 7790 & 476 \\
\hline
\end{tabular}




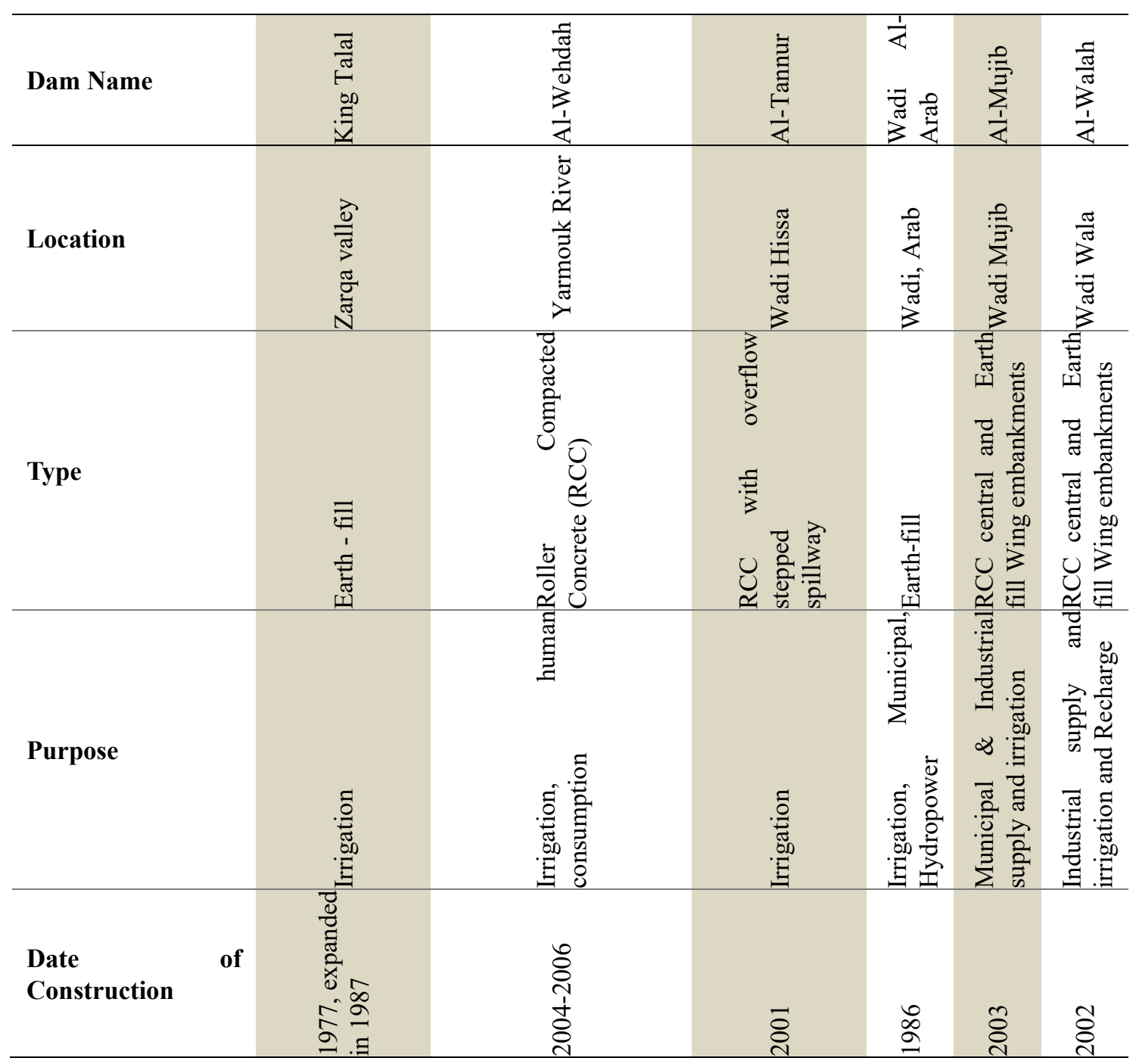

Table 2. Poor opportunity sites data

\begin{tabular}{cccccc}
\hline Dam & Location & Construction & Type & Height & $\begin{array}{c}\text { Storage } \\
\text { capacity }\end{array}$ \\
\hline Wadi Shuib & At Wadi Shuib & $\begin{array}{c}\text { Construction Completed in } \\
1969\end{array}$ & $\begin{array}{c}\text { Earth }- \\
\text { fill }\end{array}$ & $32 \mathrm{~m}$ & $1.4 \mathrm{MCM}$ \\
Kafrein & $\begin{array}{c}\text { At Wadi } \\
\text { Kafrein }\end{array}$ & $\begin{array}{c}\text { Completed in 1967, raised in } \\
1997\end{array}$ & $\begin{array}{c}\text { Earth }- \\
\text { fill }\end{array}$ & $37 \mathrm{~m}$ & $8.4 \mathrm{MCM}$ \\
Ziglabe & At Wadi Ziglab & Construction Completed in 1967 & $\begin{array}{c}\text { Earth }- \\
\text { fill }\end{array}$ & $48 \mathrm{~m}$ & $3.9 \mathrm{MCM}$ \\
$\begin{array}{c}\text { Al- } \\
\text { Karamah }\end{array}$ & $\begin{array}{c}\text { At Wadi } \\
\text { mallaha }\end{array}$ & Construction Completed in 1997 & $\begin{array}{c}\text { Earth }- \\
\text { fill }\end{array}$ & $45 \mathrm{~m}$ & $53 \mathrm{MCM}$ \\
\hline
\end{tabular}

\section{References}

Al zou'bi, M. (2010). Renewable Energy Potential and Characteristics in Jordan. Jordan Journal of Mechanical and Industrial Engineering, 4(1), 45-48.

Anagnostopoulos, J. S., \& Papantonis, D. E. (2008). Simulation and size optimization of a pumped-storage power plant for the recovery of wind-farms rejected energy. Renewable Energy, 33(7), 1685-1694. https://doi.org/10.1016/j.renene.2007.08.001 
Barbour, E., Wilson, I. A. G., Radcliffe, J., Ding, Y., \& Li, Y. (2016). A review of pumped hydro energy storage development in significant international electricity markets. Renewable and Sustainable Energy Reviews, 61, 421-432. https://doi.org/10.1016/j.rser.2016.04.019

Beaudin, M., Zareipour, H., Schellenberglabe, A., \& Rosehart, W. (2010). Energy storage for mitigating the variability of renewable electricity sources: An updated review Energy for Sustainable Development |

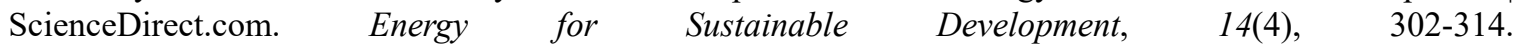
https://doi.org/10.1016/j.esd.2010.09.007

Chen, H., Cong, T. N., Yang, W., Tan, C., Li, Y., \& Ding, Y. (2009). Progress in electrical energy storage system: A critical review. Progress in Natural Science, 19(3), 291-312. https://doi.org/10.1016/j.pnsc.2008.07.014

Cochran, J., Bird, L., Heeter, J., \& Arent, D. J. (2012). Integrating Variable Renewable Energy in Electric Power Markets: Best Practices from International Experience, (April), 142.

Deane, J. P., Gallachir, B. P., \& McKeogh, E. J. (2010). Techno-economic review of existing and new pumped hydro energy storage plant. Renewable and Sustainable Energy Reviews, 14(4), 1293-1302. https://doi.org/10.1016/j.rser.2009.11.015

Denholm, P., Ela, E., Kirby, B., \& Milligan, M. (2010). The Role of Energy Storage with Renewable Electricity Generation The Role of Energy Storage with Renewable Electricity Generation. Contract, NREL/(January), 1-53. Retrieved from https://digitalscholarship.unlv.edu/renew_pubs/5

Eyer, J., \& Corey, G. (2010). Energy Storage for the Electricity Grid : Benefits and Market Potential Assessment Guide. Contract, 321(February), 232. https://doi.org/SAND2010-0815

Fanack Water. (2016). Current and Planned Infrastructural Projects - Fanack Water. Retrieved August 25, 2018, from https://water.fanack.com/jordan/water-infrastructure/current-and-planned/

Gross, R., Heptonstall, P., Leach, M., Anderson, D., Green, T., \& Skea, J. (2007). Renewables and the grid: understanding intermittency. Proceedings of the Institution of Civil Engineers - Energy, (February 2007), 3141. https://doi.org/10.1680/ener.2007.160.1.31

Holttinen, H. (2008). Estimating the impacts of wind power on power systems - summary of IEA Wind collaboration. Environmental Research Letters, 3(2), 025001. https://doi.org/10.1088/1748-9326/3/2/025001

Jordan Ministry of Energy and Mineral Resources. (2015). Annual Report 2015- Ministry of Energy and Mineral Resources. Retrieved June 25, 2018, from http://www.memr.gov.jo/echobusv3.0/SystemAssets/6df2053dee21-4fa0-ada8-613049ab7015.pdf

Jordan Ministry of Energy and Mineral Resources. (2016). Annual Report 2016- Ministry of Energy and Mineral Resources. Retrieved June 25, 2018, from http://www.memr.gov.jo/echobusv3.0/SystemAssets/505997dac229-4f65-8139-9ae8e45b0c78.pdf

Jordan Valley Authority. (n.d.). Jordan Valley Authority - Web Presence. Retrieved June 25, 2018, from http://www.jva.gov.jo/sites/en-us/SiteCollectionDocuments/dams in jordan.pdf

Namgyel, D. (2012). Wind Following with Pumped Hydroelectric Energy Storage in New Brunswick. University of New Brunswick.

Nickel, T. J. (2006). An Economic Model for Wind Generated Electricity in Alberta using Pumped Storage for Supply Management Wind-Power Generation What is Wind-Power Generation?

Rahim, N. A. (2015). The Energy Sector in Jordan. Retrieved June 25, 2018, from http://www.memr.gov.jo/Pages/viewpage.aspx?pageID=202

World Energy Organization. (2016). Wind Energy Resources-Jordan. Retrieved June 25, 2018, from https://www.worldenergy.org/data/resources/country/jordan/wind/?gclid=EAIaIQobChMIluiPpc_v2wIVCY uyCh0mRAxgEAMYAiAAEgImgfD_BwE

\section{Copyrights}

Copyright for this article is retained by the author(s), with first publication rights granted to the journal.

This is an open-access article distributed under the terms and conditions of the Creative Commons Attribution license (http://creativecommons.org/licenses/by/4.0/). 